6. 薪の然え終りは，西まりたて残火をのてさない。

7. $5 \sim 10$ 分ごとに平均缊を測る。

てのような手順と注意を必要とする。ての場合, 消長曲線のトップ（第4図B点）は自記にでもよらな

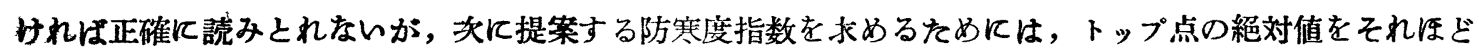
正確と知る必要はない。

\title{
5. 防寒度の表現指數
}

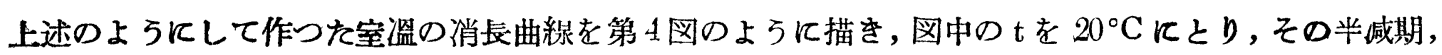
つまり, C点より $\mathrm{t} / 2=10^{\circ} \mathrm{C}$ 下つた点を図七で $\mathrm{D}$ と定めれは, $\mathrm{D}$ 点は $\mathrm{A}-\mathrm{C}$ 温度崖の半减点となる。そ

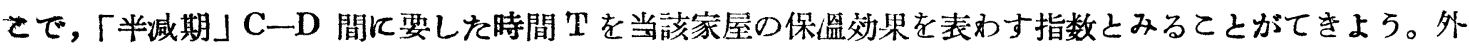
気そのものの影響は，消長曲線を探る当初に室内に取り入れてあるから，加新後の室溫下向の足どりは，

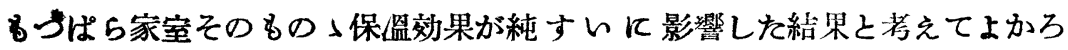
5。よつて，第 4 図の C-D間の時間 (この場合, 分て表す) を防寒指数と ナるのである。

実測した除雪員の休憩所の実例を右表に示すと，

てのような結果を得ている。

以上は実驗の順序にしたがつて, 標題の「家屋防寒度」と直接関係のない ことも述へているが, 要は, 部屋の溫度より約 $30^{\circ} \mathrm{C}$ 程度を急速に上年せし

\begin{tabular}{c|c}
\hline 家屋名称 & 䏚塞指数 $(\mathbf{T})$ \\
\hline $\mathbf{U}$ & 9 分 \\
$\mathbf{K}$ & 4 \\
$\mathrm{H}$ & 10 \\
$\mathrm{~T}$ & 12,5 \\
$\mathbf{F}$ & 3 \\
\hline
\end{tabular}
め，その下向曲線を使つて，侐度低下の半减期を防寒度とすることて，除雪作䅈員休喑所を対照とする調 查は加熱は小割の萎の裸火焰てょり，半减盄度は $10^{\circ} \mathrm{C}$ とする。を提案したんのてある。

\section{木材硬度計を利用した積雪の硬度測定器（祸報）}

T.Shide1 and S.Ono: Hardness Tester for Snow Deposite applying wood Hardness Tester

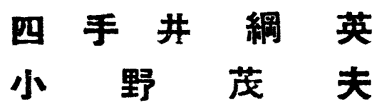

現在, 磧雪の硬度は, 普通落下式硬度計に上り則定されているが, 一䝫年冬, 木材硬度計の硬度测定法 に着眼して,ての様な方法で, 積雪の硬度を则定でを㰠すかと考え, 四手井の指導により小野が寒驗を 行いその結果を取縓めたので，予報としてその成績を報告する。佾本報告は「雪」 3,5 寻に揭載したもの である。

\section{試験 方 法}

1. 測定器の製作

落下式硬度計は，鍾を一定高所より積雪面に落下せしめ，その衝撃によつて，雪中にめり込んた深さを 測定して「硬度」の指数としているが，ての木材硬度計を利用したものは，一定の力で銛を雪中に笑込み， それルよりめり込んだ深さを測定するものである。

硬度計は, 木材面に或る一定の力て匡球して, その凹みの程度を測定する「ブリンネル硬度計」を改良 した。即ち，加区用スプリングは，乙の木材硬度則定用のるのではあまり强すを゙るので，あり合わせの鋼 鉄線を適当に巻いてそれと交換して，積雪に対して「程良い力」とした。（第1図） 


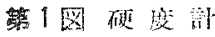

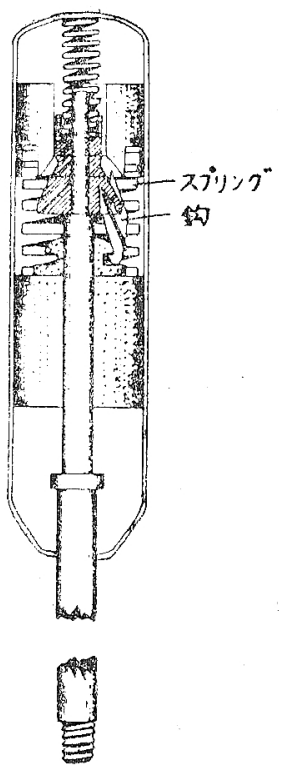

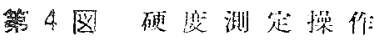
(树を保持して王人する)

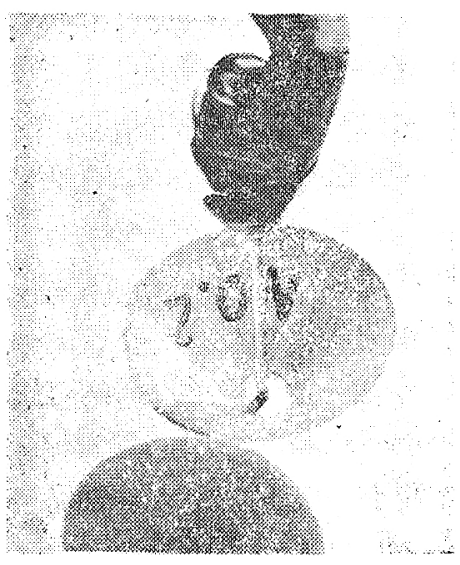

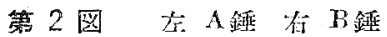

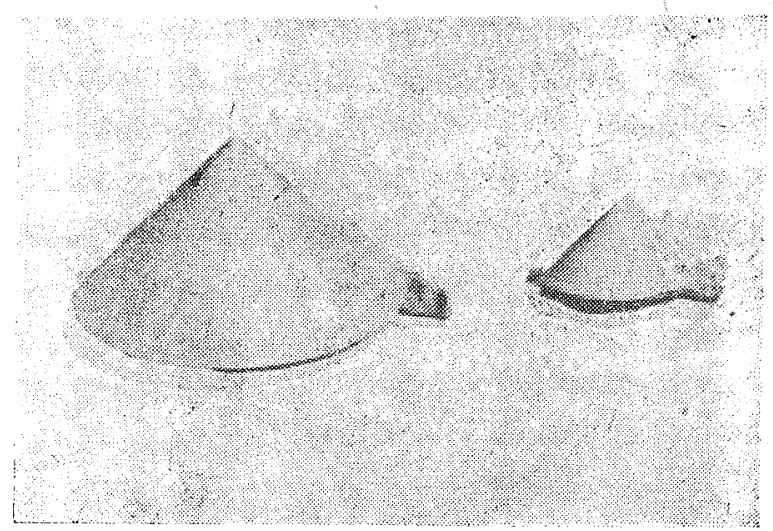

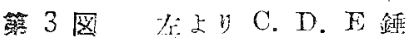

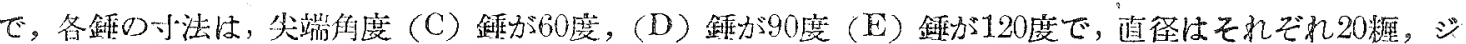
ニラルミン製である。(第3图)

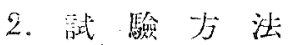

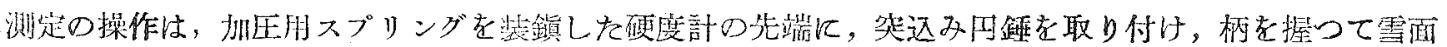

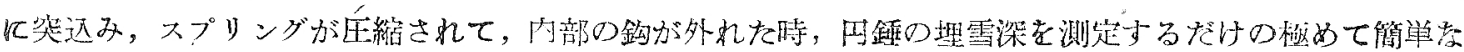
\&のである。

さて，前記の器具を次の様な組合わ呕で武驗した。

（その一）1。落下鈃之，(A）鍾之の䦭係

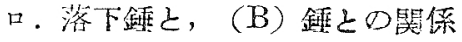

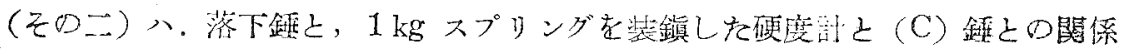

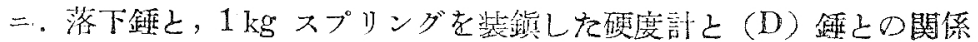

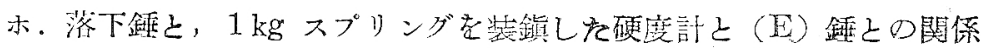


此の $1 \mathrm{~kg}$ スプリンダのほかに，をだ $2 \mathrm{~kg} \cdot \cdots . .5 \mathrm{~kg}$ スプリングがあるが，てれらの武驗は，次冬期行う 事にした。

試験成續

(其の一)

イ. 落下銛 $(x)$ と $(\mathrm{A})$ 錘 $(\mathrm{y})$ の関係

相関係数 $r=+0.950 \quad \mathrm{P}<0.01$

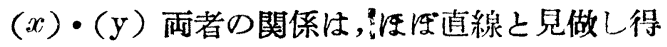

るから，一次方程式を用いて実驗式を求めると

$\mathrm{y}=0.89 x+1.50$

口. 落下銛 $(x)$ と (B) 銛 $(\mathrm{y})$ の関係 $\gamma=0.985 \quad \mathrm{P}<0.01$

$\mathrm{y}=0.91 x-3.28$

(其の二)

計算の都令上，第 6 図の $\mathrm{h}$ を埋雪深とした。

八. 落下銛 $(x)$ 上 [Sp ; $1 \mathrm{~kg},(\mathrm{C})$ 銛] $(\mathrm{y})$ との関係

$$
\begin{aligned}
& r=0.994 \quad \mathrm{p}<0.01 \\
& \mathrm{y}=1.33 x+0.20
\end{aligned}
$$

$=$. 落下銰 $(x)$ と $[\mathrm{Sp} ; 1 \mathrm{~kg},(\mathrm{D})$ 銛 $](\mathrm{y})$

\section{之の関係}

$\gamma=0.989$

$\mathrm{y}=0.93 x-0.20$

小. 落下銛 $(x)$ と $[\mathrm{Sp} ; 1 \mathrm{~kg},(\mathrm{E})$ 銛] $(\mathrm{y})$

之只関係

$$
\begin{aligned}
& \gamma=0.977 \\
& y=0.67 x-0.60
\end{aligned}
$$

让驗成縝江対与る考察

前記の成樍中, (其の一) の実驗式 1 )及 $(2)$ みると, 両者 の比例管数项は大美なく，これをほ居同一佔と見做せは，

$$
\begin{aligned}
& y_{1}=0.9 x+1.50 \\
& y_{2}=0.9 x-3.28
\end{aligned}
$$

(3) 一(4) とおけば

$$
\begin{aligned}
& y=4.78 \\
& y \cdot-5
\end{aligned}
$$

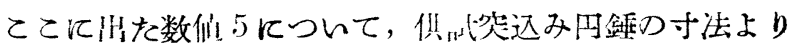
考察すると，(A)・(B) 両鏩の高さの相遠㳉

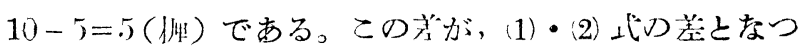

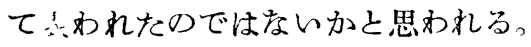

次に（期三）について考然するに，実䲆式 $\mathrm{y}=\mathrm{a} x+b$

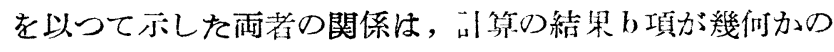
值を示している。てれは, 理論的には $b=0$ で, 従つて,

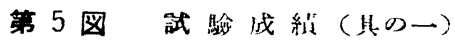

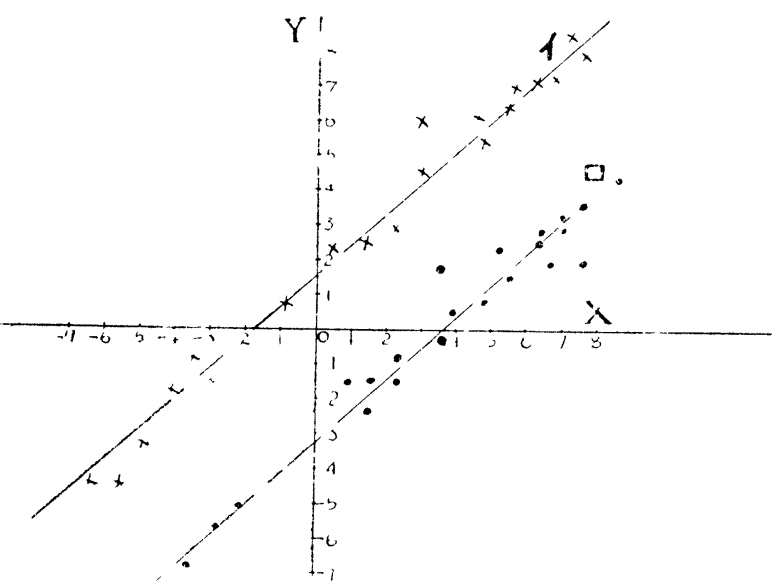

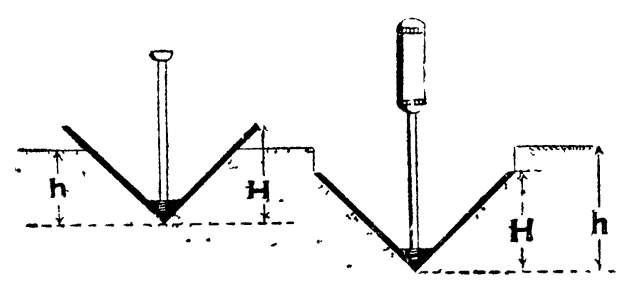

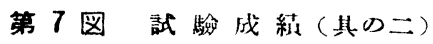

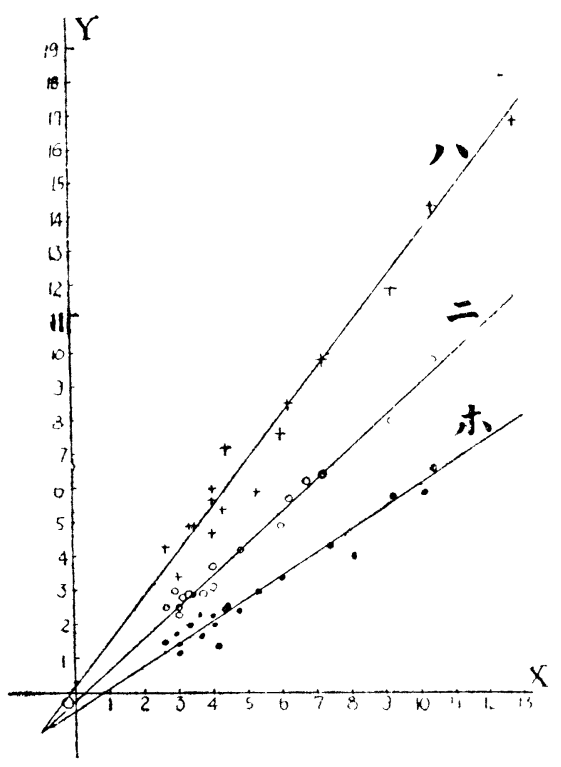

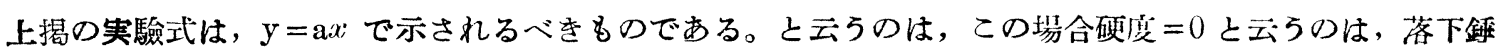


を肌ても全然复込み得ない周い物である。乙の様なものを，ての䓡込み硬度言を以つて测定を行つてみ ても，问栐に资込み行ないたろ5と宩えられるからである。

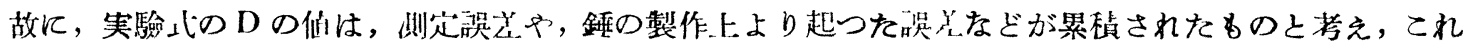

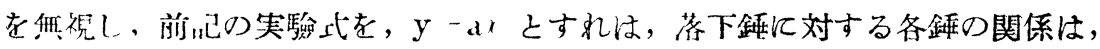
(C) 领
$y_{1}-1.39 x$
(I) 鈃
$y_{2}=0.93 x$
(E) 鋂
$y_{3}=0.67 x$

上なる。

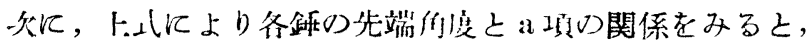

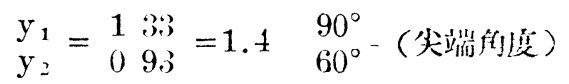

$$
\begin{aligned}
& \mathrm{y}_{3}=\mathrm{y}_{2}={ }_{0.93}^{0.97}=0.71-\frac{90^{\circ}}{120^{\circ}}- \\
& \mathrm{y}_{3}=\frac{0.67}{1.33}=0 . \overline{5}-\frac{60^{\circ}}{120^{\circ}}
\end{aligned}
$$

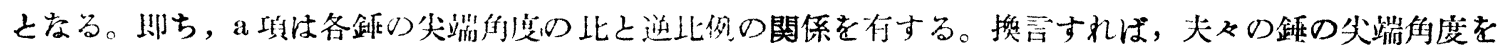

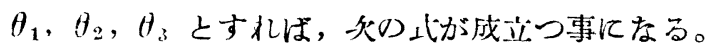

$$
y_{1}=y_{1}^{y_{2}}=-y_{3}
$$

以上の耐点を綜合すると，笑込み式の硬度いでは，普通の雪で，笑込みの力があまり大をくなければ， 四釬が多少小さくとも，尖端们度が同一であれば訂つた硬度は同一值を示し，尖端角度を变えれば，其の

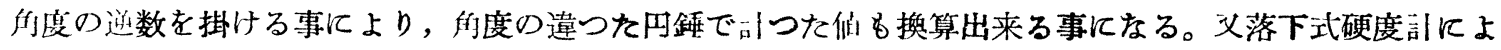

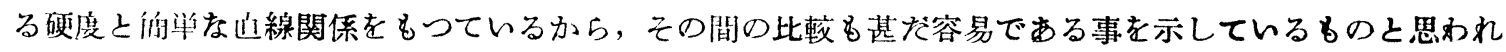
る。

\section{結 び}

以上吔した様に，此の焱込み硬度訓は，現在広く使用されている「落下式硬度計」と高度の相関々係を 行し，実朋飞供し得べき可能性恃充分みよめられるであろら。

又, 此の種の答込み烒は, どんな方向にでも随意に彫使でき, 测定の操作は至つて簡単で, 落下式の様

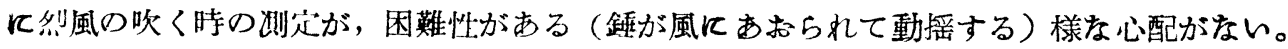

第 8 目（A）両側の凹みはキヤタピラ跡 硬度分们汹

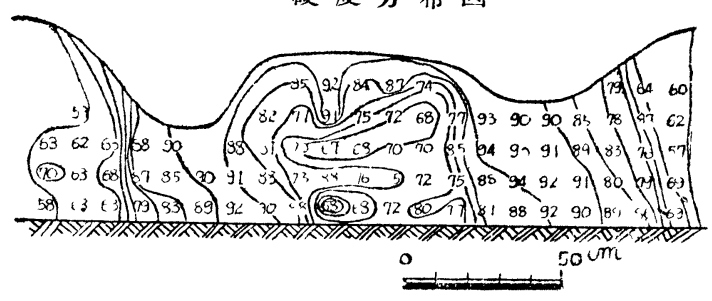

参考迄に此の硬度訂を横位に使䏳して，则资を 行つた例として，第8図を啰ける。(A)は，2.万年
第 8 图 $(B)$ 硬度分在図

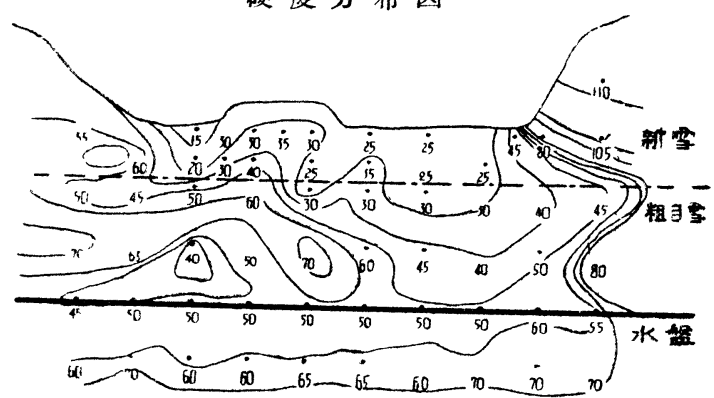

1 打, 秋时県山瀬営林署管内飞於て, トラクタ一運材叫驗を実施した際, トラクターが新雪上を通過した

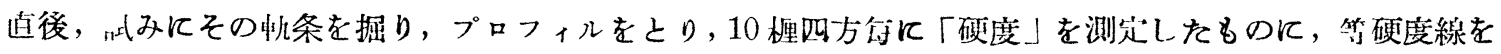
引いた「硬度分仍図」である。(B)は山形県小国営林署管内で雪琵飞関する試驗を実施した時の人曳雪㧼 運搬路のブロフィルの「硬度分布図」である。重力に対する積雪の支特力の働く出態がよく长われている。 
为上の様に, 此の硬度計は, 用途が広く, 各種の雪質調査に当つて, 有利に用レられる事がかかると思 整。

ま改善すべき点もあろらし，又実驗も充分行つていないし，相当わからない事などがあるが，今後も

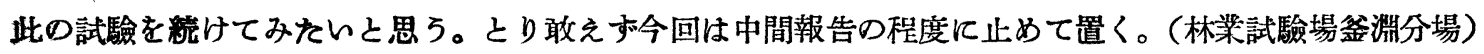

\section{電線着雪の嘱究とその雪害對策}

M. Shōda : Studies on Snow Accretion on Electrıc Wire and its Pievention

\section{塩沢・雪・実驗所 莊 田 幹 夫}

I 電楾路の雪害

II 筃線着雪の研究

1. 着水と着雪

2. 対策方法已研究方釬

3. 研究経過之設储概要

4. 研 究䊅 果

(a) 着雪型式の分類

烝型一乾型一中間型一変型一凍結型一特殊

形狀一変態
次 -

(b) 着雪発達你件

(c) 附 着 力

(d) 日射の影響

(e) 発達速度

(f) 寸法と重量との関保 (密度)

（g）その他の影䇾 (主に雪片の寸法)

(h) 気象條件の定量化 (頻度曲楾)

(1) 人篇着雪発生裝置

5. 結び（対策一の応用）

\section{I 電線路の雪害}

雪国の電栐路のうける雪害につんては，関氏*ー1がよくまとめて居られるが，ててで改めて復習してみ る。

電線路の雪害対策は, 次の様に考えると分りやすい。先す, 線路の構成要素を第1表の様化かすげ, 害をなす雪の種類別にその被害を並べると，第2表の様になる。これで分る様に，電気的なるのりる Mechanical なものの方がはるかに多い。当所に於ては，今回鉄道電化拹会に結成せられた"電線路雪害 対策委員会" の下R，1949 50! 冬期上り本格的研究を開始した。 研究に着手するとまもなく, 着雪 と着水之は明睹に区別して取扱わ なければならぬ事が明らかになつ た。更に調查担当委員の郝告によ り，国鉄通信線路の雪害復旧工費 艺けで，年間約 1 傹 2 千万円（昭 和24年) 飞薘し, その大部分が 「着雪」による事も, 汪心゙確実と なつた。そてで、特に着雪を主に して研究をす〉めた。以下, 新兒

第 1 表 電線 路の構成要素

\begin{tabular}{|c|c|c|c|c|c|}
\hline $\begin{array}{l}\text { 電楾路の } \\
\text { 種類成要素 }\end{array}$ & 通信線路 & 选電線路 & 配 電線 路 & 電事線 路 & その他 \\
\hline 線 & 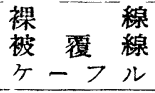 & 撚 & 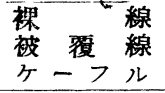 & $\begin{array}{c}\text { 吊架 線 } \\
\text { ト口䈍一線 } \\
\text { 饋 電 線 }\end{array}$ & \\
\hline 絕 緣 物 & ピン碍子 & $\begin{array}{l}\text { ピン碍子 } \\
\text { 繁垂碍子 }\end{array}$ & $\begin{array}{l}\text { ピン碍子 } \\
\text { 懸金碍子 }\end{array}$ & $\begin{array}{l}\text { ヒ碍子 } \\
\text { 篎垂碍子 } \\
\text { 饋電線碍子 }\end{array}$ & \\
\hline 汥 持 物 & $\begin{array}{l}\text { 腕木、腕金 } \\
\text { 木杜。鉄柱 } \\
\text { コークリ } \\
\text { - 一杜 }\end{array}$ & $\begin{array}{l}\text { 腕金 } \\
\text { 鉄 塔 }\end{array}$ & $\begin{array}{c}\text { 腕木、腕金 } \\
\text { 木杜、鉄杜 } \\
\text { コンクリ } \\
\text {-ト杜 }\end{array}$ & $\begin{array}{l}\text { 單ビームト } \\
\text { ラスヒーム } \\
\text { ホ柱。鉄杜 } \\
\text { בンクリ } \\
\text { 一ト杜 }\end{array}$ & \\
\hline 補强 材 & 支 & & 線 & 茂 & \\
\hline 保宇設備 & & & & & \\
\hline
\end{tabular}

